\title{
Pluralised Humanities and Learning from the Past
}

\author{
Janine Rogers
}

"The humanities" is a strange term: grammatically plural, it is nonetheless often spoken of as a singular, a cluster of different disciplines - such as literature, philosophy, and history, that rose from the liberal arts, and that now form units such as faculties and schools in modern universities. In the institutional, disciplinary context the inherent plurality of the humanities is often forgotten, thus, there have been attempts to categorize multiple forms of humanities expertise that resist the traditional disciplinary designations, refocusing humanities work on topics, themes, and outcomes such as "civic humanities" or "blue humanities." When remembered, the plural nature of the humanities tends to be located in the diversity between disciplines: the links between literature and history, for example, or philosophy and classics. But the plurality of the humanities can, and should, also be understood as multiplicity within disciplines. All of the traditional established disciplines within Western university curricula are methodologically and hermeneutically diverse, and becoming increasingly so as they engage the intellectual and cultural benefits of interdisciplinarity.

For example, I increasingly think of my field as "literary humanities" instead of English literature, for the conventional expectations of literary studies - that it works with certain forms of language, especially written texts, as a cultural or artistic production - extends to include a plethora of other disciplinary practices. ${ }^{1}$ Literary humanities engage material culture, film and media studies, drama, visual culture studies, philosophies, psychology, sociology, anthropology, archaeology, cognitive studies, and cultural history of virtually every ilk, including the history of science. All of these disciplines participate in addressing questions that lie at the heart of literary analysis: What is the nature of language-based knowledge, or poēsis in the largest sense of the term? And how does that knowledge interact with other forms of knowledge, including the material world, lived experience and other disciplinary practices? Thinking in terms of the literary humanities, and constructing other, more pluralized understandings of the humanities, resists a totalizing idea of the arts, humanities or science and rejects binaries which have often been used polemically. Pluralized humanities create more points of contact to knowledges that lie outside the traditional academic fields of the humanities altogether, such as the sciences and now, the ScienceHumanities: this develops affinities between not just academic disciplines, but cultural categories of knowledge that are deep, real and effective. My question here is: to what extent is this playing with the pluralizing possibilities in the humanities a kind of remembering of what we, culturally, have forgotten about knowledge? This question comes to me frequently, because my home discipline is medieval English literature, and I am often confronted with the idea that my excitement about connecting to other disciplines, especially the sciences, would have been met with a shrug or a puzzled stare, if one of the great medieval encyclopaedists, or even Chaucer, were to materialize in front of me.

\section{Getting medieval}

Contemporary disciplines present themselves as fields of knowledge with deep intellectual traditions, but they are just as much, if not more, administrative structures and examples of academic professional boundary-making within universities that are 
increasingly operating as businesses (Becher and Trowler 41). The modern emphasis on distinctions between academic disciplines is tied to economic and political histories, especially late capitalism and neo-liberalism, that commodify expertise (Brown 175200; Donoghue). In these categorizations, there is always a narrative of triumphalism, and the narrative structure itself is assumed to be linear - "progressive" (Burke 19, 11416). This structure of disciplinary history employs the same narrative of "revolution" that Bruno Latour critiques as the myth of modernity. As he points out in We Have Never Been Modern, one of the foundational self-definitions of science studies is the split between the sciences and the humanities. In turn, this split is often posited as one of the hallmarks of modernity, an intellectual move that elides the complexities of "modernity" as well (Introduction 634-35). Older forms of knowledge, or knowledge of older things, are almost always on the wrong side of these post-Enlightenment narratives (Latour 35): to get medieval becomes a joke in a gangster film.

But medieval philosophers, once brought up to speed on the definition of its two semantic parts, would not consider the general concepts behind ScienceHumanities oxymoronic, contradictory, or in any other way troubling. In medieval scholasticism, not only were discrete disciplinary categories designated differently than our categories (for example, music as a part of mathematics), the underlying principles of knowledge categorization in the Middle Ages (itself a construct of a particular narrative of modernity) were different from ours. This difference is perhaps most neatly summarized in the terms trivium and quadrivium, which share the etymological root "via," meaning path or way. Hovering behind that metaphor is the idea that paths can intersect and meet. Our modern theories of "disciplines," derived partly from Enlightenment epistemologies that privilege objectivity and other post-Cartesian epistemologies that construct strict boundaries between knower and known, and partly from post-war economics, tend to stress boundaries between, not meeting places of, different ways of knowing (Burke 44-6). Or as Isidore of Seville put it in Etymologies, "a discipline is concerned with things that have only one possible outcome" (39). I argue, along with other medievalists, such as Kellie Robertson, Carol Symes, Bruce Holsinger, Andrew Cole and D. Vance Smith (as well as a few early modernists Cynthia Pyle, for example), that the migration of knowledge between medieval and post-medieval is more continuous than the myth of modernity allows, and that we can look to the Middle Ages for models of thinking about our disciplinary practices. This is important to initiatives such as the ScienceHumanities. The very principle of recognizing, and sometimes emphasizing, methodological and theoretical convergences over divergences can create new learning opportunities. ScienceHumanities aspires to such a convergence framework, and can use early cultures, including medieval cultures, as resources.

\section{What has medieval knowledge ever done for us?}

Medieval scholastic epistemologies, including their understanding of structural relationships between categories of knowledge, are some of the things we might want to re-examine to rethink our own knowledge work. We have every right, from the position of cultural distance, to select positive aspects of knowledge cultures and leave the rest (I am not arguing for a return to geocentric theological cosmology). The most important thing we might select as a resource from the Middle Ages is its instinct to find where the paths cross. Its holism, in that respect. Now, it cannot be said that medieval thinkers did not categorize and rank areas of knowledge at all: Mary FranklinBrown has remarked that ordering information was a medieval "habit of mind" (72), and indeed a philosopher like Isidore would position language (grammar) as a 
fundamental ontology, which is especially convenient for literary humanists. But it is the underlying motivation, or premise, for ordering that knowledge that is different from modern, corporate-based sorting behaviours seen recently in our universities. Since medieval philosophy ultimately laid all of creation in the mind of God, a poetic expression of the divine, the unity of existence was assumed (Robertson "Medieval Materialism," 111-12). Ordering was a human tool to navigate that existence, massive and incomprehensible as it was. Hierarchies in the earthly realm, like the so-called Great Chain of Being, were attempts to grasp the ungraspable nature of God. In many ways, such metrics were gestures of intellectual humility. While such methods gave rise to the scientific method, the underlying motivation for studying natural history was quite different in the medieval period, and well into the early modern period. To insist that one aspect of the divine mind was better than another was heresy, human hubris beyond all reason. Of course, this also resulted in pronounced conservatism in medieval thought - something we would be better to edit out. But these days I am feeling that the medieval instinct for epistemological connections, and their reverence for knowledge in general, would not be bad things to reclaim.

Medieval holism as principle of knowledge meets (although does not match exactly) theoretical frameworks such as posthumanism with its intersecting interests in postcolonialism and ecocriticism. Specifically, because medieval philosophy saw all existence as divine, there was an implicit critical awareness of existence beyond the human. The material world was very much alive, vital, for medieval thinkers (Robertson "Medieval Materialism," 115). Although humans occupied the top-ranked position in the earthly world, this did not restrict the subjectivity of other forms of existence, as the posthumanist theorist might now put it (Cole 2013; Holsinger). Not only that, but since all of the subjects of existence were part of the great poem of divine creation, they were all at least theoretically invested with a life-force and a form of knowledge, or, as Alain of Lille wrote: "Every creature in the world is like a book and a picture to us, and a mirror; a faithful representation of our life, our death, our condition, our end" (trans. Ziolkowski, 7).

The ethical danger with holism is that it can elide important differences. ${ }^{2}$ European cultural hegemony, medieval or otherwise, might be seen as a form of holism that whitewashes colonized cultures. But I would argue that medieval-style holism is of a different order than colonial hegemony, and that it runs a level below and in fact resists the colonized, corporatized academy and its forms of "epistemic violence" that silence and devalue medieval knowledge in ways that are coherent with decolonization (Symes 715-19). In the Americas, Africa, Asia, and Oceania, decolonizing the academy involves disrupting disciplinary categories and structures in order to make room for indigenous knowledge and other silenced cultural narratives (Strega and Brown, Kovach, Tuhiwai Smith, and Chilisa). Re-approaching cultures of the past engages many similar (but not identical) ethical and intellectual issues that are involved in decolonization processes. This is relevant to the ScienceHumanities, because by recognizing the knowledges of medieval cultures, the resistance to historical constructions of modernity that are constructed at the expense of pre-modernity might disrupt perhaps the most pernicious division in modern Western intellectual traditions, that between the humanities and sciences. In regard to the relationship between decolonisation and post-Enlightenment disciplinarity, I would point out that Indigenous Studies programmes are especially subject to this science-humanities divide, as they are usually placed in humanities or social science faculties, not science faculties, which reinforces rather than disrupts cultural power dynamics between both the humanities and the sciences, and colonizer and indigenous. But beyond the ethos of the medieval 
hermeneutical holism, some of the specific precepts of medieval culture might inspire new thinking on, and exchanges between, the sciences and the humanities.

\section{ScienceHumanities and medieval ways of knowing}

There are things, quite simply, that medieval knowers knew, that we have forgotten. Most simply, we have managed to forget things like the recipe found recently in a medieval manuscript that seems to be able to treat some forms of persistent infection (Harrison et al). But the most interesting things we have forgotten are not specific bits of data, but entire ways, or via, of approaching knowledge. Recent work in the field of medieval studies, especially medieval literature, is challenging disciplinary, historical, and temporal distinctions alike: of special interest are the ways in which medieval cosmology, with its enmeshed, multi-valent understanding of identity and nature, challenges distinctions between humans and non-human animals (see recent work by Steel, Kay, MacCracken, Robertson). The medieval book, which lies at the heart of both western European epistemology and material cultures of knowledge, holds a special place in these discussions. Made directly from fauna, flora, and minerals, medieval manuscripts were material microcosms of the world, contracting together the ecologies of the world of things and the world of ideas (Franklin-Brown 48). The parchment page, in particular, is where these material and immaterial worlds merge to challenge intellectual boundaries that determine so many of our contemporary academic and epistemological boundaries: parchment manuscripts are "the site of convergence between seeming incompatibles: between bare life and intellectual life, livestock and literacy, the history of the book and the seemingly ahistorical existence of nonhuman animals" (Kay 2). Such challenges can become resources in multidisciplinary projects initiated from both humanist and scientist approaches.

For example, at the Centre for Geogenetics, part of the Natural History Museum at the University of Copenhagen, Matthew Collins has developed several projects in the field of bioarcheology that address both scientific and humanist research questions about medieval books. One of these, a project called Beast to Craft (B2C) will use protein analysis, DNA capture, digital imaging, and archival analysis to analyze parchment in medieval manuscripts. The B2C project engages what Martha Rust has called medieval "codicological consciousness" of the Middle Ages from a bioarchaeological approach (9). That consciousness included the physical book as part of the locus of meaning of a text, and in fact diminished the distinction between text and book that we would make today. The impacts of projects like $\mathrm{B} 2 \mathrm{C}$ feed directly into literary and cultural questions. The ecologies of medieval book culture extend from forage or grazing animals to the synapses of the reader - the reader of the present, as well as the past. In the skin of manuscripts Collins can read the complex histories of livestock production and migration that formed the material of medieval literate culture. From a literary perspective, Collins' work contributes to our understanding of how book-making products were produced and circulated, findings that in their most prosaic application might be compared with the circulation of specific texts in compiler culture. But the patterns of parchment circulation in medieval literary culture are not merely historical or technical questions when, as Sarah Kay notes, the page of skin becomes an extension of the reader's skin (especially given the tactile reading methods of the Middle Ages), and the knowledge of the book, physically and allegorically expressed in the complex organizational structures of the manuscript, are "extended outward to form a space from mind to page that the reader inhabits" (142).

The "codicological consciousness" of medieval culture can therefore be expanded far beyond individuals: it is in fact a codicological cosmology. We speak now 
of knowledge ecosystems or knowledge ecologies that are analogous to systems of the natural world (or studies of systems of the natural world), but in a codicological cosmology the structures of nature and knowledge are not merely analogous, but synonymous (Rogers 5-11, Parkes 59-60; Franklin-Brown 63-128). The material life of our knowledge cannot be divorced from our world of ideas (writing this, I am after all tapping binary code into a machine containing minerals mined in tenebrous circumstances in far-off lands). The medieval understanding of the holism of "bare life and intellectual life" (Kay 2) inflects much of what I do in my own research, and provides resources that I can bring to other knowledge communities. A research community at my own university has challenged me to dig deep into my medieval resources. A multi-disciplinary research network on Lyme Disease led by biologist Vett Lloyd includes myself and other humanities scholars, as well as social scientists and scientists, to address this highly complex disease (Lloyd). As a specialist in medieval literate culture, I look to the medieval past for interpretive models of disease that understand it as not simply a biological crisis but also a crisis of a wider ecological structure. In the Middle Ages illness was a sign that the equilibrium of the body, which is composed of the same elements of the world, has become unbalanced: "so is the world's whole frame / Quite out of joint," wrote John Donne in The First Anniversary, himself on the cusp between the medieval and modern (11. 191-92). While the medieval humoral medical theory underpinning Donne's poem is useless to us in one sense, its accompanying concepts of the enmeshment between the individual body and natural ecosystems are exactly the sorts of intellectual resources we need to address the Lyme crisis, along with other diseases of the Anthropocene.

Lyme disease poses both scientific and cultural challenges: the disease's development is the result of climate change; diagnosis and treatment are politically inflected; and individual behaviour can impact both risk and prognosis. Communication between all sides - scientific, medical, political, social, economic, and individual - is critical, and a professor of literature can offer communicative methods and strategies. Similarly, the humanist capacity for stepping back and tracking broad cultural patterns, connecting history and the present, and investing in cross-cultural solutions is also critical for this project. So too, might be some medieval (or what Latour might call "amodern") solutions for treatment and care. We can look to strategies such as the use of placebo, self-soothing, mindfulness and prayer, the roles of music, poetry and art, and social engagements such as acts of altruism, as parts of a network of behaviour that address, if not cure, life with chronic diseases like Lyme. One possible contribution to the Lyme crisis in Maritime Canada is that "hybrid vigour" (the benefit that an organism gets from outbreeding) may be contributing to the spread of the ticks and possibly also the virulence of bacteria. Our approach to this disease should also be a vigorous hybrid of science and culture, a metaphor that might extend well to the ScienceHumanities.

\section{The compaignye of sundry folk}

The Canterbury Tales begins with a description of the turning of the season from winter to spring, and places the desire to go on pilgrimages, to renew ourselves spiritually, socially, and physically, within the cosmological context of seasonal regeneration. As the impetus to both the pilgrimage and narrative, spring produces the text itself another level of cosmological codicology. As Kellie Robertson has recently explored in her magisterial Nature Speaks, this is not mere poetic convention, but rather is an enactment of the vigorous - alive and life-giving - holism of medieval epistemologies. In the Canterbury Tales, the gathering of the pilgrims, with their different knowledges and different stories, is a structural analogy to the united diversity of existence writ (and 
literally writ, in the mind of the medieval God) large. The collectivity, the diversity, and the premise of movement, of pilgrimage, appeals to me greatly as a literary analogy for the ScienceHumanities.

The medievals themselves actually had a great sense of the past as company, and in fact based their entire learning culture on collecting and assembling knowledges of the past, with the intention of both preserving it, but also re-deploying it. Like us, they had to excise and retool some of what they wanted from the past to fit their cosmology. Their epistemological philosophies centralized the role of the compiler the one who brings diverse sources, ideas, and texts together and produces from this something new. Their thinking about compiling activities was highly sophisticated and provided a philosophical underpinning to all intellectual work. To capture the creative investment of the compiling method they turned to exquisite metaphors, themselves borrowed from past thinkers, and destined to be re-used in the future. They were bees collecting nectar from flowers to produce honey (Hathaway 25, 42). They were dwarves on giant's shoulders (Stock 371-2). They saw thinking as essentially collaborative, with their ancient sources being part of the collaborative network alongside contemporary intellectual colleagues: a network of scholarly friends, as they often put it.

Effectively (and affectively, also), knowledge generated in a community of scholarly friends, which can be expanded in principle to all scholars and all scholarship, is imbued with a kind of holism that is analogous to friendship itself as a structure. In Ascelin of Augsburg's eleventh-century treatise on astrolabes he references Cicero and Symmachus to buttress the idea that friendship both gets scholarly things done and makes those things virtuous: friendship requires us to "seek honourable things" that our scholarly friends request of us and "grant them" (Burnett 351). Friendship gives form and shape to knowledge - it is in fact part of the craftwork of knowledge. But friendship (like scholarship), is also crafted itself, as communities and individuals come together. The suffix -ship, of course, comes from the Germanic sceppan and gesceap; to create, creation. Scop is the Anglo-Saxon word for bard or poet (like the Greek poessis). This gives us also the transitive verb "shape: to create, form, construct, model, mould, fashion, bring into desired or definite figure or form" $(O E D)$. This is why we say we make friends with someone.

Initiatives like the ScienceHumanities can shape new communities and make new networks of scholarly friends, which include past forms of knowledge and that resist triumphalist, progressive myths of knowledge history. Doing so resists some of the dangerous competitiveness and hierarchizing of academic disciplines that target the humanities, in particular, today. The ScienceHumanities can take the great strengths of humanities interdisciplinarity and extend it to the sciences in active, shared engagements, not just positioning the sciences as objects of inquiry, and not merely being a handmaiden to scientific inquiry. This allows humanitists and scientists to present a unified front to resist the fracturing, monetizing, and wall-building to which our universities are increasingly subjected, often by policy makers or perceptions of the market. Most importantly, it develops the kind of knowledge community that is essential for addressing the global challenges of our time: global challenges by definition require holistic, and therefore medieval, approaches. 


\section{Notes}

1. My use of this term is not related to the "Literature Humanities" program at Columbia University, or the International Journal of the Literary Humanities, once published by Common Ground publishing, which has been included in some lists of "predatory" open access publishing.

2. The term "holism" itself has a contentious relationship with colonization: although coined by Jan Smuts as a biologically-inflected philosophical concept, that fact that Smuts was a Prime Minister of pre-apartheid (but still segregationist) South Africa brings the term's political implications into a bright light. Smuts is a complex figure in terms of racism and colonialism: he held many racist and segregationist beliefs, but also argued against apartheid as a political system. 


\section{Works Cited}

Becher, Tony, and Paul R. Trowler. Academic Tribes and Territories. 2nd ed., SRHE and Open UP, 2001.

Brown, Wendy. Undoing the Demos: Neoliberalism's Stealth Revolution. Zone, 2015. Burke, Peter. What is the History of Knowledge? Polity, 2016.

Burnett, Charles. "King Ptolemy and Alchandreus the Philosopher: The Earliest Texts on the Astrolabe and Arabic Astrology at Fleury, Micy and Chartres." Annals of Science vol. 55, no. 4, 1998. pp. 329-368.

Chilisa, Bagele. Indigenous Research Methodologies. Sage, 2011.

Cole, Andrew. "The Call of Things: A Critique of Object Oriented Ontology." Minnesota Review, vol. 8, new series, 2013, pp. 106-18.

Cole, Andrew, and D. Vance Smith. "Outside Modernity." The Legitimacy of the Middle Ages: On the Unwritten History of Theory, edited by Andrew Cole and D. Vance Smith, Duke UP, 2010, pp. 1-36.

Donne, John. "An Anatomy of the World (The First Anniversary)." The Norton Anthology of English Literature, edited by M.H. Abrams et al, $5^{\text {th }}$ ed., Norton, 1986, pp. 1091-96.

Donoghue, Frank. The Last Professors: The Corporate University and the Fate of the Humanities. Fordham UP, 2009.

Franklin-Brown, Mary. Reading the World: Encyclopedic Writing in the Scholastic Age. U of Chicago P, 2012.

Harrison, Freya, et al. "A 1,000-Year-Old Antimicrobial Remedy with Antistaphylococcal Activity." mBio vol. 6, no. 3, 2015, mbio.asm.org/ content/6/4/e01129-15. Accessed 12 Sept 2017.

Hathaway, Neil. "Compilatio: From Plagiarism to Compiling." Viator vol. 20, 1989, pp. 19-44.

Holsinger, Bruce. "Object-Oriented Mythography." Minnesota Review vol. 8, new series, 2013, pp. 119-30.

"Introduction." The American Historical Review, vol. 116, no. 3, 2011, pp. 631-637. JSTOR, www.jstor.org/stable/23308217.

Kay, Sarah. Animal Skins and the Reading Self in Medieval Latin and French Bestiaries. U of Chicago P, 2017.

Kovach, Margaret. Indigenous Methodologies: Characteristics, Conversations, and Contexts. U of Toronto P, 2010.

Latour, Bruno. We Have Never Been Modern. Translated by Catherine Porter, Harvard UP, 1993.

Lloyd, Vett. www.mtalymenetwork.ca/. Accessed 12 Sept. 2017.

McCracken, Peggy. In the Skin of a Beast: Sovereignty and Animality in Medieval France, U of Chicago P, 2017.

Pyle, Cynthia M. "Bridging the Gap: A Different View of Renaissance Humanism and Science." The Making of the Humanities Volume 1: Early Modern Europe, edited by Rens Bod, Jaap Maat and Thijs Weststeijn, Amsterdam UP, 2010, pp. 39-58.

Robertson, Kellie. "Medieval Materialism: A Manifesto," Exemplaria, vol. 22 no. 2, 2010, pp. 99-118.

---. Nature Speaks: Medieval Literature and Aristotelian Philosophy. U of Pennsylvania P, 2017.

Rogers, Janine. "Compiling Creation: Medieval Codicology and Images of Early Modern Collections." Visualizing the Text: From Manuscript Culture to the Age 
of Caricature, edited by Lauren Beck and Christina Ionescu, U of Delaware $\mathrm{P}$, 2017, pp. 3-23.

Rust, Martha. Imaginary Worlds in Medieval Books: Exploring the Manuscript Matrix. Palgrave, 2009.

Steel, Karl. How to Make a Human: Animals and Violence in the Middle Ages. Ohio State UP, 2011.

Stock, Brian. "Antiqui and Moderni as 'Giants' and 'Dwarfs': A Reflection of Popular Culture.” Modern Philology, vol. 76, no. 4, 1979, pp. 370-74.

Strega, Susan, and Leslie Brown. Research as Resistance: Revisiting Critical, Indigenous, and Anti-Oppressive Approaches. 2nd ed., Canadian Scholar's P and Women's P, 2015.

Symes, Carol. "When We Talk about Modernity." The American Historical Review, vol. 116, no. 3, 2011, pp. 715-26. JSTOR, www.jstor.org/stable/23308224.

Tuhiwai Smith, Linda. Decolonizing Methodologies: Research and Indigenous Peoples. 2nd ed., Zed, 2012.

Ziolkowski, Jan M. "Literary Genre and Animal Symbolism." Animals and the Symbolic in Medieval Art and Literature, edited by L.A.J.R. Houwen, Forsten, 1997. 